\title{
Failure of GLP-1(7-36)amide to affect glycogenesis in rat skeletal muscle
}

\author{
C. Fürnsinn, K. Ebner, W. Waldhäusl \\ Department of Medicine III, Division of Endocrinology and Metabolism, University of Vienna, Vienna, Austria
}

\begin{abstract}
Summary Glucagon-like peptide-1(7-36)amide has been described as exerting potent glycogenic action and as stimulating glycolysis in skeletal muscle. We exposed isolated rat soleus muscle strips to various concentrations of glucagon-like peptide-1(7-36) amide $\left(10^{-11}-10^{-6} \mathrm{~mol} / \mathrm{l}\right)$ or insulin $\left(10^{-10}-10^{-7} \mathrm{~mol} / \mathrm{l}\right)$ and determined the respective effects on glucose metabolism. Insulin markedly increased the rate of glucose incorporation into glycogen with a maximal effect at $10^{-8} \mathrm{~mol} / \mathrm{l}$ insulin $(348 \pm 46 \%$ of intraindividual control experiment, $p<0.005$ ), while glucagonlike peptide-1(7-36)amide was without an effect (e.g. $10^{-11} \mathrm{~mol} / \mathrm{l}, 96 \pm 10 \% ; 10^{-9} \mathrm{~mol} / \mathrm{l}, 104 \pm 9 \%$; $10^{-7} \mathrm{~mol} / \mathrm{l}, 121 \pm 13 \%$; not significant). Likewise, glu-
\end{abstract}

cagon-like peptide-1(7-36)amide did not affect the rate of ${ }^{3} \mathrm{H}$-2-deoxy-glucose transport or glycogen content of soleus muscle strips. The rates of aerobic or anaerobic glycolysis were also not increased. The findings were independent of peptide source and of employed muscle size. Our results do not suggest any effect of glucagon-like peptide-1(7-36)amide on skeletal muscle glucose metabolism and, hence, are in contrast to data derived from similar experiments by others. [Diabetologia (1995) 38: 864-867]

Key words Glucagon-like peptide-1(7-36)amide, skeletal muscle, glycogen synthesis, glycolysis, glucose transport.
Glucagon-like peptide-1(7-36)amide (GLP-1(7-36) amide) potentiates glucose-stimulated insulin release $[1,2]$ presumably via specific receptors on pancreatic beta cells [3]. Since stimulation of pancreatic beta cells by GLP-1(7-36)amide has been shown to depend on the presence of glucose [1], GLP-1 (7-36)amide may be regarded as a potentially useful tool in the treatment of diabetic patients capable of endogenous insulin production.

In addition to its insulinotropic potency, GLP-1(736)amide has been noted to enhance insulin sensitivity in patients with insulin-dependent diabetes [2]

Received: 29 December 1994 and in revised form: 13 March 1995

Corresponding author: Dr. C.Fürnsinn, Department of Medicine III, Division of Endocrinology and Metabolism, Währinger Gürtel 18-20, A-1090 Vienna, Austria

Abbreviations: GLP-1(7-36)amide, glucagon-like peptide-1(736)amide; BSA, bovine serum albumin; KRB, Krebs-Ringer bicarbonate buffer ( $\mathrm{pH} 7.4)$. and to exert potent glycogenic action in isolated rat hepatocytes via a putative specific GLP-1(7-36) amide receptor [4]. Since the presence of GLP1(7-36)amide receptors has also been suggested in skeletal muscle [5], the peptide's glycogenic potential has also been investigated in muscle. In a recent paper, Villanueva-Peñacarillo et al. [6] investigated the influence of GLP-1(7-36)amide on glucose metabolism in isolated rat soleus muscle, describing glycolytic and potent glycogenic effects. Such glycogenic action would be beneficial in hyperglycaemic diabetic states. However, in a series of similar experiments, we were unable to reproduce those findings.

\section{Materials and methods}

Animals. Male Sprague-Dawley rats (Him: OFA/SPF) were purchased from the Institute for Experimental Animal Research (Himberg, Austria). They were kept at a 12-h lightdark cycle at $23^{\circ} \mathrm{C}$. Conventional laboratory diet and tap water were provided ad libitum until the evening before the ani- 
Table 1. A. Rates of glucose incorporation into glycogen, of $\mathrm{CO}_{2}$ and lactate release, 2-deoxy-glucose transport and glycogen content in isolated soleus muscle strips from rats weighing $120-160 \mathrm{~g}$ exposed to various concentrations of GLP-1(7-36) amide (Sigma) and insulin, respectively. $n$ given in parenthesis

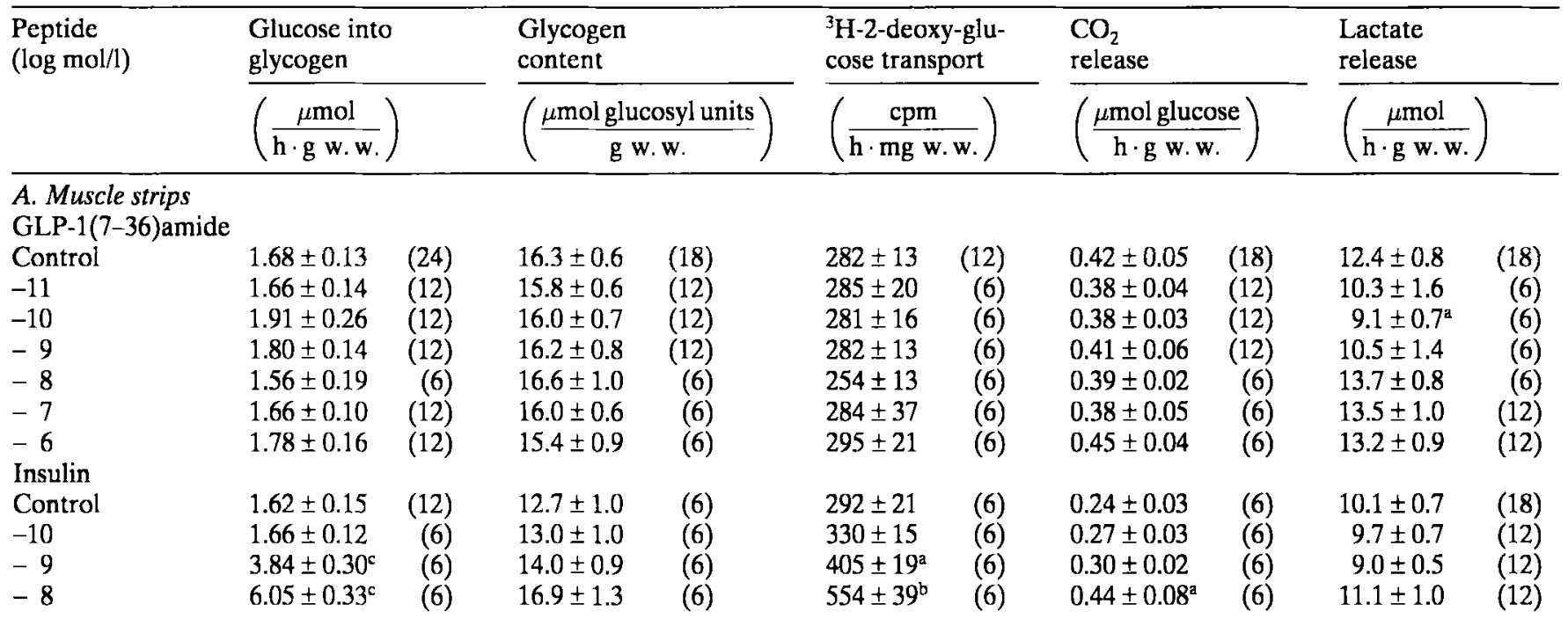

B. Whole muscle

\begin{tabular}{|c|c|c|c|c|c|}
\hline $\begin{array}{l}\text { GLP-1(7-36) } \\
\text { amide } \\
(\log \mathrm{mol} / \mathrm{l})\end{array}$ & $\begin{array}{l}\text { Glucose int } \\
\left(\frac{\mu \mathrm{mol}}{\mathrm{h} \cdot \mathrm{g} \mathrm{w} \cdot \mathrm{w} .}\right.\end{array}$ & ycogen & $\begin{array}{l}\mathrm{CO}_{2} \text { releas } \\
\left(\frac{\mu \mathrm{mol} \text { gluc }}{\mathrm{h} \cdot \mathrm{g} \mathrm{w} .}\right.\end{array}$ & & \\
\hline & Sigma & Peninsula & Sigma & Peninsula & $n$ (each) \\
\hline $\begin{array}{l}\text { Control } \\
-10\end{array}$ & $\begin{array}{l}0.85 \pm 0.13 \\
0.63 \pm 0.07\end{array}$ & $\begin{array}{l}0.94 \pm 0.19 \\
0.93 \pm 0.12\end{array}$ & $\begin{array}{l}0.15 \pm 0.01 \\
0.14 \pm 0.01\end{array}$ & $\begin{array}{l}0.18 \pm 0.03 \\
0.16 \pm 0.01\end{array}$ & 8 \\
\hline $\begin{array}{l}\text { Control } \\
-9\end{array}$ & $\begin{array}{l}0.90 \pm 0.22 \\
0.82 \pm 0.19\end{array}$ & $\begin{array}{l}1.03 \pm 0.14 \\
0.82 \pm 0.12\end{array}$ & $\begin{array}{l}0.14 \pm 0.02 \\
0.14 \pm 0.02\end{array}$ & $\begin{array}{l}0.15 \pm 0.02 \\
0.14 \pm 0.02\end{array}$ & 6 \\
\hline $\begin{array}{l}\text { Control } \\
-8\end{array}$ & $\begin{array}{l}0.64 \pm 0.09 \\
0.69 \pm 0.12\end{array}$ & $\begin{array}{l}0.69 \pm 0.06 \\
0.78 \pm 0.07^{\mathrm{a}}\end{array}$ & $\begin{array}{l}0.13 \pm 0.01 \\
0.15 \pm 0.01\end{array}$ & $\begin{array}{l}0.15 \pm 0.01 \\
0.14 \pm 0.01\end{array}$ & 10 \\
\hline
\end{tabular}

Means \pm SEM; w. w., Wet weight of muscle; controls are contralateral soleus muscles incubated in the absence of GLP-1(7-36) amide; ${ }^{\mathrm{a}} p<0.05 ;{ }^{\mathrm{b}} p<0.005 ;{ }^{\mathrm{c}} p<0.0005$ vs control mals were killed, when only food was withdrawn. Fasted rats were killed by cervical dislocation between 08.30 and 09.30 hours.

GLP-1(7-36)amide. GLP-1(7-36)amide was purchased from Sigma (St.Louis, Mo., USA) or from Peninsula (Belmont, Calif., USA; peptide purity according to manufacturers' information: $97 \%$ and $98 \%$, respectively), dissolved in $0.01 \mathrm{~N} \mathrm{HCl}$ at a $-20^{\circ} \mathrm{C}$. Immediately before using, the solution was thawed and dissolved in Krebs-Ringer bicarbonate buffer ( $\mathrm{pH}$ 7.4) (KRB) to reach the respective final concentrations.

Incubation procedures. Unless stated otherwise, two longitudinal soleus muscle strips per leg were prepared immediately after killing from rats weighing $120-160 \mathrm{~g}$ (i. e. four strips per rat) as previously described [7]. Muscle strips were weighed, tied under tension on stainless steel clips, and transferred into silicone-coated 25-ml Erlenmeyer flasks containing $3 \mathrm{ml} \mathrm{KRB}$ supplemented with $5.5 \mathrm{mmol} / \mathrm{l}$ glucose, $1 \%$ bovine serum albumin (BSA), and $5 \mathrm{mmol} / \mathrm{l}$ pyruvate. Flasks were placed in a shaking waterbath $\left(37^{\circ} \mathrm{C} ; 130 \mathrm{cycles} / \mathrm{min}\right)$ and continuously gassed with $95 \% \mathrm{O}_{2}: 5 \% \mathrm{CO}_{2}$ for the whole experimental period. After $30 \mathrm{~min}$ of preincubation, muscles were transferred to another set of flasks and incubated for $60 \mathrm{~min}$ in $3 \mathrm{ml} \mathrm{KRB}$ containing the same concentrations of glucose and BSA, but concentration of $100 \mu \mathrm{mol} / \mathrm{l}$, and stored as $50-\mu \mathrm{l}$ aliquots at
B. Rates of glucose conversion into glycogen and $\mathrm{CO}_{2}$, respectively, in whole isolated soleus muscle from rats weighing 200$250 \mathrm{~g}$ exposed to various concentrations of GLP-1(7-36)amide from Sigma or Peninsula, respectively 


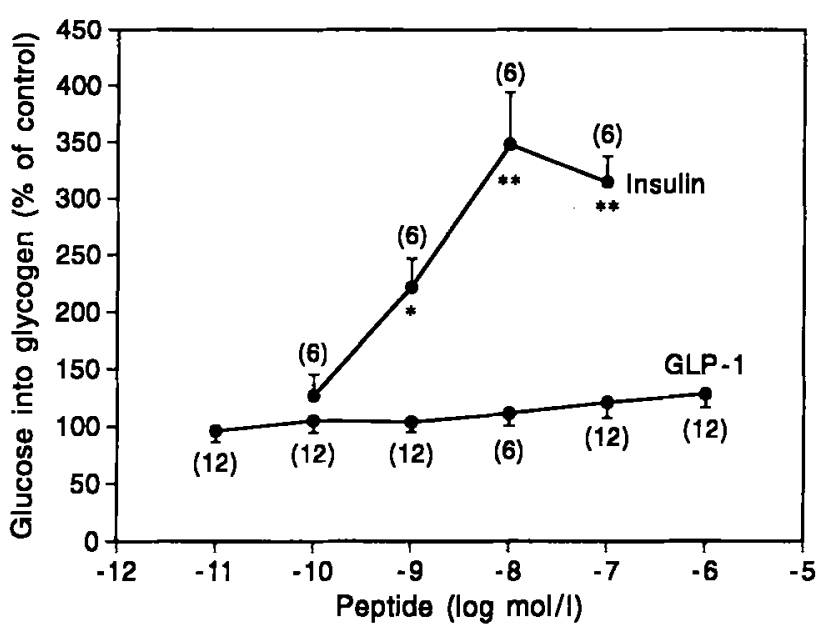

Fig.1. Rates of glucose incorporation into glycogen in isolated rat soleus muscle strips exposed to various concentrations of GLP-1(7-36)amide or insulin. Data are given as \% of an intraindividual control experiment in the absence of peptide. Means \pm SEM; $n$ given in parenthesis. ${ }^{*} p<0.01 ;{ }^{* *} p<0.005$ vs control (i.e. $100 \%$ ) by paired Student's $t$-test

was corrected for ${ }^{3} \mathrm{H}$ trapped in the extracellular space using $\left[{ }^{14} \mathrm{C}\right]$ sucrose as a space marker. Results from different experiments were also corrected for respective differences in ${ }^{3} \mathrm{H}$ concentration in the incubation media. Rates of glycogen synthesis and aerobic glycolysis were calculated from conversion of $\left[{ }^{14} \mathrm{C}\right]$ glucose to $\left[{ }^{14} \mathrm{C}\right]$ glycogen or ${ }^{14} \mathrm{CO}_{2}[8,9]$.

\section{Statistical analysis}

Data given as percent refer to control muscle strips obtained from the same individual rat and incubated in the absence of GLP-1(7-36)amide or insulin. Data are given as means \pm SEM. The data derived from this explorative study were interpreted in a descriptive manner calculating $p$-values by twotailed Student's $t$-test, paired or unpaired as appropriate. A p value of less than 0.05 was considered significant.

\section{Results}

Data obtained from muscle strips incubated for $1 \mathrm{~h}$ in the presence of GLP-1(7-36)amide (Sigma) at concentrations ranging from $10 \mathrm{pmol} / 1$ to $1 \mu \mathrm{mol} / 1$ (Table 1) demonstrate failure of GLP-1(7-36)amide to affect the rates of 2-deoxy-glucose transport, of glucose incorporation into glycogen stores, or of muscle glycogen content as found after termination of the experiment. Likewise, GLP-1(7-36)amide did not influence aerobic or anaerobic glycolysis except for a transient decrease in lactate release from muscles incubated with $100 \mathrm{pmol} / \mathrm{l}$ GLP-1(7-36)amide $(p<0.05)$. Insulin, at concentrations ranging from $0.1-10 \mathrm{nmol} / 1$ dose-dependently stimulated glycogen synthesis, glucose transport, and aerobic glycolysis (Table 1).

GLP-1(7-36)amide did not exert any effect on the rate of glucose incorporation into glycogen calculated as percentage of intraindividual control experi- ments, whereas insulin dose-dependently induced glycogen synthesis with maximal stimulation reached at $10 \mathrm{nmol} / 1$ ( $p<0.005$; Fig. 1$)$.

Compared to soleus muscle strips (Table 1), incubation of whole soleus muscles obtained from larger rats resulted in somewhat lower rates of 2-deoxy-glucose transport $\left(127 \pm 9 \mathrm{cpm} \cdot \mathrm{mg}^{-1} \cdot \mathrm{h}^{-1} ; n=8\right)$ and of conversion of glucose into $\mathrm{CO}_{2}$ and glycogen (Table 1). Rates of lactate release were similar in split (Table 1) and whole $\left(11.0 \pm 0.5 \mu \mathrm{mol} \cdot \mathrm{g}^{-1} \cdot \mathrm{h}^{-1} ; n=8\right)$ muscle preparations. Independent of peptide source (Sigma or Peninsula, respectively), glycogen synthesis and aerobic glycolysis in whole muscle preparations were unaffected by the presence of GLP-1 (7-36)amide at concentrations ranging from 0.1$10 \mathrm{nmol} / \mathrm{l}$, except for a minor increase in glycogen synthesis at $10 \mathrm{nmol} / 1$ GLP-1(7-36)amide from Peninsula $(p<0.05$, Table 1$)$.

\section{Discussion}

Villanueva-Peñacarrillo et al. [6] recently described potent effects of GLP-1(7-36)amide on glucose metabolism in isolated rat soleus muscle at peptide concentrations ranging from $10 \mathrm{pmol} / \mathrm{l}$ to $100 \mathrm{nmol} / \mathrm{l}$. Maximal rate of glycogen synthesis was obtained at $100 \mathrm{pmol} / \mathrm{l}$, when the rate of glucose incorporation into glycogen stores was greater than $250 \%$ of control values. Such potent glycogenic action in skeletal muscle [6] and liver [4] together with potentiation of glucose-stimulated insulin release $[1,2]$ would make GLP-1(7-36)amide an ideal candidate for the treatment of non-insulin-dependent diabetes.

Although applying similar experimental methods this study was not able to reproduce those findings and did not indicate any stimulation by GLP-1(7-36) amide of glucose metabolism in skeletal muscle. Using the same source of tissue, we measured the rate of glucose incorporation into glycogen and muscle glycogen content in the presence and absence of GLP-1(7-36)amide concentrations ranging from $10 \mathrm{pmol} / \mathrm{l}$ to $1 \mu \mathrm{mol} / \mathrm{l}$, but failed to provide any evidence for a glycogenic potential. Furthermore, the described stimulation of aerobic as well as anaerobic glycolysis by GLP-1(7-36)amide [6] was absent in our experiments and no alterations were found in the rate of 2-deoxy-glucose transport. Expressing our data for the reason of direct comparison as percentage of control experiments (Fig.1), sensitivity and responsiveness of split rat soleus muscle to insulin were essentially identical in the two soleus muscle incubation studies ([6] vs this study). Such similar insulin effects are opposed to strikingly contradictory results obtained for GLP-1(7-36)amide action.

Evident differences in experimental setup that may have caused a contradictory outcome from the two studies include employment by others [6] of 
much larger muscle preparations and of peptide from a different source (Peninsula). Size of incubated muscles may influence results, because hypoxia is known to prevail in internal fibers of large muscle preparations [10]. Also, to simulate the experimental setup applied by others [6], we prepared whole soleus muscles from rats weighing $200-250 \mathrm{~g}$ and purchased peptide from Peninsula. In the larger preparations, rates of lactate release did not indicate hypoxia. However, glycogen synthesis and aerobic glycolysis, which have been reported to be markedly stimulated by GLP-1(7-36)amide [6], remained unaffected independent of peptide source (Table 1). The minor effect of $10 \mathrm{nmol} / \mathrm{l}$ GLP-1(7-36)amide from Peninsula on glycogen synthesis may represent a statistical type 1 error rather than a GLP-1(7-36)amide effect, since such errors are to be expected with respect to the number of tests performed. Hence, neither different muscle size nor different peptide source can explain contradictory results obtained from the two studies.

The data suggest that some undiscovered experimental pitfall resulted in inadequate conclusions in at least one of the studies. Such potential pitfalls leading to negative results in our experiments may relate to loss of biological activity of the GLP-1(7-36) amide employed or to inapproriate handling. Such interpretation, however, appears very unlikely considering that GLP-1(7-36)amide from two different sources was used and that a significant increase in the rate of glycogen synthesis was found in the presence of $10 \mathrm{pmol} / 1$ GLP-1(7-36)amide by others [6], but not at a 100,000-fold higher peptide concentration in this study. Considering conversely potential pitfalls resulting in erroneous insulin-like action, carry-over effects of insulin due to repeated use of incubation flasks in subsequent experiments has to be taken into account. After incubation of muscle strips with $100 \mathrm{nmol} / 1$ insulin in our experimental setup, flushing the used flasks with water and detergent solution followed by drying at $100^{\circ} \mathrm{C}$ for several hours was apparently not sufficient to remove insulin completely from the siliconized flask surface. Thus, insulin retained by glass surface went into solution during a subsequent experiment and increased the rate of glucose incorporation into glycogen $(4.36 \pm 0.33$ vs control, $\left.1.53 \pm 0.15 \mu \mathrm{mol} \cdot \mathrm{g}^{-1} \cdot \mathrm{h}^{-1} ; p<0.001\right)$. Although we do not have any information whether such insulin carry-over effects are a possible explanation for the putative insulin-like GLP-1(7-36)amide action observed by others [6], the given example may illustrate that experimental pitfalls must be ta- ken into consideration, when highly contradictory findings are obtained from similar experimental protocols.

Taken together, our findings failed to demonstrate any glycogenic or glycolytic effect of GLP-1(7-36) amide in isolated rat soleus muscle and thus argues against any insulin-like action in skeletal muscle.

Acknowledgements. We appreciate the help of B. Leighton, Ph. D., Department of Biochemistry, University of Oxford, who taught us the soleus muscle incubation techniques, of B. Schneider, Ph. D., Institute for Medical Statistics and Documentation, University of Vienna, for statistical advice, and of the animal caretakers at the Biomedical Research Center, University of Vienna. This work was supported in part by the Austrian "Fonds zur Förderung der wissenschaftlichen Forschung", Grant no. P09987-MED.

\section{References}

1. Ørskov C (1992) Glucagon-like peptide-1, a new hormone of the enteroinsular axis. Diabetologia 35: 701-711

2. Gutniak M, Ørskov C, Holst JJ, Ahren B, Efendic S (1992) Antidiabetogenic effect of glucagon-like peptide-1 (7-36) amide in normal subjects and patients with diabetes mellitus. New Engl J Med 326: 1316-1322

3. Thorens B (1992) Expression cloning of the pancreatic beta cell receptor for the gluco-incretin hormone glucagon-like peptide-1. Proc Natl Acad Sci USA 89: 8641-8645

4. Valverde I, Morales M, Clemente F et al. (1994) Glucagonlike peptide-1: a potent glycogenic hormone. FEBS letters 349: 313-316

5. Wheeler MB, Lu M, Dillon JS, Leng X-H, Chen C, Boyd AE (1993) Functional expression of the rat glucagon-like peptide-I receptor, evidence for coupling to both adenylyl cyclase and phospholipase-C. Endocrinology 133: 57-62

6. Villanueva-Peñacarrillo $\mathrm{ML}$, Alcantara AI, Clemente $\mathrm{F}$, Delgado E, Valverde I (1994) Potent glycogenic effect of GLP-1(7-36)amide in rat skeletal muscle. Diabetologia 37: $1163-1166$

7. Crettaz M, Prentki M, Zanietti D, Jeanrenaud B (1980) Insulin resistance in soleus muscle from obese Zucker rats. Involvement of several defective sites. Biochem J 186: 525-534

8. Challiss RAJ, Lozeman FJ, Leighton B, Newsholme EA (1986) Effects of the beta-adrenoreceptor agonist isoprenaline on insulin-sensitivity in soleus muscles of the rat. Biochem J 233: 377-381

9. Leighton B, Budohoski L, Lozeman FJ, Challiss RAJ, Newsholme EA (1985) The effects of prostaglandin E1, E2, and F2alpha and indomethacin on the sensitivity of glycolysis and glycogen synthesis to insulin in stripped soleus muscle of the rat. Biochem J 227: 337-340

10. Bonen A, Clark MG, Henriksen EJ (1994) Experimental approaches in muscle metabolism hindlimb perfusion and isolated muscle incubations. Am J Physiol 266: E1-E16 